\title{
PENGGUNAAN $C \& C$ LEARNING DALAM MENINGKATKAN KEMAMPUAN INTERAKSI DAN BERDAYA SAING POSITIF PADA KELAS READING
}

\author{
Irene Trisisca Rusdiyanti (Corresponding Author) \\ Universitas Kanjuruhan Malang \\ Jl. S. Supriyadi 48 Malang, Indonesia \\ Phone: (+6285933037953) e-mail: irenetrisisca@ymail.com \\ Siti Mafulah \\ Universitas Kanjuruhan Malang \\ Jl. S. Supriyadi 48 Malang, Indonesia \\ Phone: (+628175003101) e-mail: siti_mafulah@unikama.ac.id
}

\begin{abstract}
Abstrak: Kemampuan interaksi dan daya saing positif sangatlah dibutuhkan mahasiswa sebagai bekal menghadapi persaingan dunia kerja usai lulus dari perguruan tinggi, maka dari itu sebisa mungkin rasa itu harus dipupuk dan di tanamkan dalam diri masing-masing mahasiswa. Salah satunya adalah dengan pembelajaran yang mengandung kompetisi namun tetap berkooperasi dan kolaborasi yaitu $C \& C$ learning. Metode yang dipakai dalam penelitian ini adalah PTK dengan empat siklus yang diadopsi dari Kemmis \& Taggart (1988) yang memiliki empat langkah: perencanaan tindakan, pelaksanaan tindakan, pengamatan, dan refleksi. Instrumen yang digunakan adalah lembar pengamatan, kuisioner dan tes. Hasil dari penelitian ini menyatakan bahwa pada siklus pertama hasil penelitian menunjukkan kurang berhasil karena hanya $46.15 \%$ mahasiswa memperoleh nilai dibawah 80 . hal ini belum memenuhi kriteria keberhasilan yang telah ditetapkan. Sedangkan pada siklus kedua jumlah mahasiswa yang memperoleh nilai diatas 80 sebanyak $88.46 \%$. Dengan perlehan ini maka penelitian disimpulkan telah sukses. Dari hasil kuisioner diperoleh respon dari mahasiswa sebagai berikut: sebanyak 24 mahasiswa $(92,30 \%)$ mahasiswa menyatakan senang dan mampu berinteraksi denagn baik. 25 mahasiswa $(96,15 \%)$ menyatakan mampu menyatakan ide tanpa beban. Sehingga dapat disimpulkan bahwa C\&C learning mmampu meningkatkan kemampuan interkasi dan berdaya saing positif dalam mata kuliah interpretive reading.
\end{abstract}

Kata kunci : C\&C Learning, PTK, kemampuan kompetitif

\section{PENDAHULUAN}

Saat ini dunia pendidikan semakin berkembang dan menantang seturut dengan berkembangnya era globalisasi dan MEA. Calon pendidik harus benar-benar mempersiapkan diri sehingga nantinya sungguh siap dan tidak tergeser oleh jaman dalam menerapkan ilmu yang sudah mereka dapatkan sebagai bentuk dari kompetensi positif di dunia kerja. Mereka hendaknya membekali diri dengan kemampuan serta pemikiran yang kritis dan kreatif supaya mampu untuk menjawab tantangan di masa depan. Pemikiran yang kritis dan kreatif tersebut bisa didapat salah satunya dengan membaca atau "reading." Dengan membaca, seseorang mampu menembus dimensi tempat karena dengan membaca, seseorang bisa mengetahui segala peristiwa yang berada di luar sana dengan cepat tanpa harus menjangkau tempat tersebut secara nyata. Membaca tidak hanya sesederhana yang disampaikan diatsa, namun membaca adalah hal yang lebih kompleks. Hal ini sesuai dengan pendapat Braunger dan Lewis (2001:3) 
ISSN : 23557083

Volume 4 Nomor 1 Juni 2017

membaca itu kompleks yang meliputi proses interaktif, penggunaan ketrampilan dasar dan strategi untuk mendapatkan arti dari suatu bacaan. Jadi jelas bahwa dalam membaca, di dalam suatu kelas misalnya, para siswa membuat suatu komunikasi dengan guru dengan cara mengaktifkan pengetahuan yang dimiliki sebelumnya (prior knowledge) dan menafsirkan atau menarik kesimpulan. Pemahaman merupakan tujuan utama dari membaca dan pemahaman mengacu pada suatu kegiatan yang menghubungkan pemikiran dan ide pembaca dengan apa yang disampaikan penulis dalam bacaan. Dengan kata lain, pengalaman dan ide pembaca benar-benar penting untuk menghubungkan apa yang mereka baca dalam suatu bacaan.

Sedangkan menurut Soedarso (2006: 4) membaca adalah aktivitas yang kompleks dengan menggerakkan sejumlah besar tindakan yang terpisah-pisah. Aktivitas yang kompleks dalam membaca meliputi pengertian dan khayalan, mengamati, serta mengingat-ingat.

Lebih lanjut pengertian membaca menurut Kholid A. H dan Lilis S (1997: 140), Membaca adalah mengemukakan atau membunyikan rangkaian lambang lambang bahan tulis yang dilihatnya dari huruf menjadi kata, kemudian menjadi frasa, kalimat dan seterusnya.

Interpretative reading, di Universitas Kanjuruhan Malang, merupakan mata kuliah wajib yang harus ditempuh oleh para mahasiswa Pendidikan Bahasa Inggris semester 3 (tiga). Pada mata kuliah ini para mahasiswa diberi pembelajaran untuk memahami suatu teks dan mendiskusikan arti yang harfiah dan arti yang tidak tertulis secara langsung atau arti tersirat di dalam bacaan. Dalam pembelajaran Interpretative reading dosen tidak hanya menyiapkan teks bacaan, namun dapat meminta mahasiswa untuk mempersiapkan bacaan yang sepadan dengan level mereka. Hal ini dilakukan supaya mahasiswa mempunyai kemandirian dalam berfikir dan bekerja. Dosen bisa meminta mereka bekerja secara individu maupun bekerja secara bersama-sama dalam kelompok untuk menganalisa isi bacaan, mencari ide pokok dan ide tambahan dan juga mencari arti beberapa kata penting baik yang tersurat maupun yang tersirat. Ini dimaksudkan agar mahasiswa bisa bekerja sama dengan orang lain dan bisa saling menolong.

Agar mahasiswa dapat menyajikan pembelajaran membaca dengan baik serta mencapai target yang ditetapkan, diperlukan suatu stategi yang menarik sekaligus menantang sehingga para siswa nantinya juga bisa mempunyai kebebasan dalam mengemukakan ide mereka secara aktif, kreatif serta mereka mampu berkompetisi. Salah satu strateginya adalah dengan menggunakan $C \& C$ Learning. $C \& C$ Learning merupakan suatu strategi yang menggabungkan kemampuan berinteraksi dengan teman dan bersaing secara sehat dalam mengemukakan ide setelah membaca suatu teks.

C \& C Learning merupakan suatu tehnik pembelajaran yang menggabungkan teknik Cooperative Learning dan Competitive learning. Cooperative Learning merupakan suatu pendekatan dalam pembelajaran yang memaksimalkan penggunaan kegiatan bekerja sama yang melibatkan dua siswa atau grup di dalam kelas (Richards and Rodgers, 2002: 192). lebih lanjut Cooperative Learning menekankan keterlibatan siswa dalam membagikan apa yang ada dalam pemikiran mereka, saling menguji kemampuan, mendapatkan pandangan berdasarkan kritikan teman, dan mengembangkan 
pengertian dengan cara mendengarkan sesama teman yang mempunyai pengertian yang sama (Cooper, 1999: 272).

Sedangkan Jacobs, et al (1996) mengemukakan bahwa Cooperative Learning bertujuan untu membantu para anggota dalam suatu grup dan memberi pengalaman kepada para anggota grup dalam bekerja sama. Ini merupakan suatu cara dimana para siswa membagikan ide dan mereka bekerjasama untuk saling belajar dan bertanggung jawab atas sesama teman di dalam kelompok. Jadi mereka saling belajar sebagai suatu tim.

Dari uraian diatas, tujuan dilakukan penelitian ini adalah untuk mendeskripsikan bagaimana penggunaan $\mathrm{C} \& \mathrm{C}$ learning dalam meningkatkan kemampuan interaksi dan bekerjasama pada mata kuliah Reading dan bagaimana $C \& \quad C$ Learning dapat mengembangkan daya saing yang positif terhadap mahasiswa Prodi Pendidikan Bahasa Inggris Universitas Kanjuruhan dalam kelas Interpretative Reading.

\section{METODE}

Penelitian ini menggunakan desain Penelitian Tindakan Kelas (PTK). Desain ini dilakukan dengan tujuan untuk memeriksa atau menemukan bagaimana $C \& C$ Learning mampu meningkatkan kreatifitas dan juga meningkatkan kemampuan membaca (reading) pada mahasiswa semester tiga jurusan Bahasa Inggris Kanjuruhan Malang. Penelitian Tindakan Kelas ini dilakukan di dalam kelas guna memperbaiki kualitas proses pengajaran supaya proses pengajaran membaca menjadi lebih efektif.

Penelitian Tindakan Kelas ini menerapkan empat tahapan yakni perencanaan, penerapan perencanaan, pengamatan, serta evaluasi proses penerapan metode yang diadopsi dari Kemmis\&Taggart (1988). Hasil dari evaluasi ini menentukan apakah penelitian perlu dilanjutkan untuk mengadakan siklus berikutnya atau tidak. Jika hasil yang diperoleh tidak sesuai dengan kriteria keberhasilan maka peneliti akan melanjutkan ke siklus ke dua.

Penelitian ini diterapkan pada mahasisa Program Studi Pendidikan Bahasa Inggris semester tiga Universitas Kanjuruhan Malang yang mengambil mata kuliah Interpretative Reading.

Secara rinci dalam tiap tahapan penelitian ini di jelaskan sebagai berikut: pertama tahap perencanaan. Pada tahap ini, yang harus diselesaikan adalah (1) mempersiapkan strategi pengajaran, setelah melakukan studi pendahuluan didapatkan bahwa kualitas membaca mehsiswa kurang begitu baik dan hanya beberapa mahasiswa yang benar-benar mampu mengkreasikan ide dampai dengan menyimpulkan, maka dari itu kerjasama sangat dibutuhkan dalam hal ini. $C \& C$ learning adalah solusi terbaik untuk mengatasi permasalahan ini. Selain bekerja sama untuk meningkatkan kreatifitas namun tetap mengedepankan kemampuan individu yakni kompetitif dalam menjawab pertanyaan yang diberikan pengampu matakuliah (2) mempersiapkan materi. Materi yang disampaikan harus disesuaikan dengan tingkatan mahasiswa, materi yang dipakai dalam penelitian ini adalah materi dengan level intermediate mengingat subyek penelitian ini adalah mahasiswa semester tiga. (3) menyusun kriteria keberhasilan. Kriteria keberhasilan disusun untuk mengetahui apakah pengajaran berhasil atau tidak. Apabila hasil dari penelitian nanti sesuai dengan kriteria keberhasilan, maka penelitian tindakan kelas bisa diakhiri. Namun sebaliknya apabila hasil tidak sesuai dengan kriteria keberhasilan maka 
ISSN : 23557083

Volume 4 Nomor 1 Juni 2017

akan dilakukan penerapan siklus ke 2 . Kriteria keberhasilan bagi penelitian ini adalah $80 \%$ dari total jumlah mahasiswa yang mengikuti Mata Kuliah reading mampu mencapai nilai 80 dan aktif dalam mengikuti pembelajaran dengan menggunakan $C \& C$ Learning.

Tahap kedua adalah pelaksanaan. Pelaksanaan merupakan perwujudan dari apa yang sudah direncanakan. Dalam pelaksanaan peneliti pertama berperan sebagai pengajar sedangkan peneliti ke 2 berperan sebagai kolaborator yang bertindak sebagai pengamat. Dalam penelitian ini, peneliti dalam pengajaran mata kuliah Reading memberikan strategi bagaimana meningkatkan kerjasama yang baik antar teman dan bagaimana mempunyai daya saing yang positif melalui penerapan $C \& C$ Learning. Pelaksanaannya akan dilakukan selama satu semester yaitu selama semester ganjil. Tes diadakan pada akhir siklus.

Tahap ketiga adalah tahap pengamatan. Tahap ini merupakan proses pengambilan data mengenai semua aspek dan kejadian yang berlangsung selama penerapan teknik yang sudah ditentukan. Tujuan dari pengamatan adalah mengamati apakah penerapan strategi yang dilakukan di dalam kelas mengatasi permasalahan atau tidak. Peneliti mempersiapkan lembar observasi, lembar catatan tambahan, dan kuesioner. Lembar observasi digunakan untuk mengumpulkan data mengenai kegiatan pengajar dan mahasiswa selama proses belajar mengajar. Lembar tersebut terdiri dari keterlibatan mahasiswa, kegiatan mahasiswa selama proses belajar, dan performa pengajar.

Tahap terakhir adalah refleksi. Aktifitas utama dalam tahap ini adalah membandingkan hasil pengamatan dan kriteria keberhasilan yang ditentukan. Hasil refleksi digunakan untuk mempertimbangkan tindakan berikutnya. Apabila hasil dari refleksi dalam suatu siklus menunjukkan bahwa hasil tidak memenuhi kriteria yang telah ditentukan, maka peneliti harus menganalisa hal-hal yang harus diperbaiki, melakukan rencana kembali dan menerapkannya pada siklus selanjutnya.

\section{HASIL DAN PEMBAHASAN}

Setelah penelitian dilakukan, maka didapat hasil dari penelitian sebagai berikut:

\section{Siklus 1}

Data awal mengenai ketrampilan membaca para mahasiswa didapat peneliti dari nilai harian mereka. Tercatat bahwa nilai rata-rata para mahasiswa kelas ini adalah 71, 07. Ketrampilan membaca memang tidak bisa didapat secara instant. Perlu ketekunan dan pembiasaan. Karenanya peneliti merasa perlu untuk menerapkan $\mathrm{C} \& \mathrm{C}$ Learning untuk meningkatkan kemampuan mahasiswa dalam membaca.berikut adalah hasil nilai rata-rata dari nilai harian mahasiswa.

Table3.1 Hasil Rata-Rata Nilai Harian

\begin{tabular}{cccc}
\hline No & Jumlah mahasiswa & Nilai total & Nilai rata-rata \\
\hline 1 & 26 & 1848 & 71.07 \\
\hline
\end{tabular}

Siklus 1 dilaksanakan sejak tanggal 9 Mei 2017 hingga 19 Mei 2017 dengan melalui 4 tahapan yakni perencanaan, penerapan, pengamatan, dan evaluasi. Setiap tatap muka dilaksanakan dalam 100 menit dengan rincian: pertemuan pertama dilaksanakan pada hari Selasa tanggal 9 Mei 2017, pertemuan kedua pada hari Jumat tanggal 12 Mei 2017, pertemuan ketiga pada hari Selasa tanggal 16 Mei 2017, dan tes dilaksanakan pada hari Jumat tanggal 19 
Mei 2017. Berikut ini adalah gambaran kegiatan siklus 1:

\section{Perencanaan 1}

Hasil analisa masalah mendapati bahwa mahasiswa tampak pasif dan kurang bersemangat dalam mengikuti mata kuliah membaca. Beberapa dari mereka bahkan terlihat beberapa kali menguap. Mahasiswa yang cerdas tampak bosan dalam menjawab pertanyaan-pertanyaan yang disajikan dibawah teks bacaan. Mereka merasa kurang tertantang dengan pertanyaan-pertanyaan yang ada. Berdasarkan pengamatan tersebut, peneliti berencana menerapkan $\mathrm{C} \& \mathrm{C}$ Learning untuk meningkatkan kreatifitas mereka.

\section{Pelaksanaan 1}

Pertemuan pertama dilaksanakan pada hari Selasa tanggal 9 Mei 2017 dengan rincian kegiatan sebagai berikut: Pertama kegiatan pembukaan. Dalam kegiatan ini dosen memberikan salam pembuka dan memberi penjelasan mengenai materi. Ini berlangsung selama 20 menit. Kedua, kegiatan inti dilakukan dalam 60 menit. Mahasiswa dibagi menjadi beberapa kelompok dan mendapatkan teks yang berbeda. Kemudian mereka mencoba memahami teks tersebut dalam 10 menit. Setelah memahami teks tersebut, mereka membuat 4 pertanyaan berdasarkan teks tersebut. Setelah itu dosen membagikan teks yang dimiliki oleh kelompok lain. Ini berarti setiap kelompok mempunyai teks yang berbeda dan mereka diminta untuk memahami teks bacaan tersebut dalam 25 menit. Disinilah metode cooperative learning berperan. Setelah semua bacaan terpahami, maka bacaan-bacaan tersebut dibalik dan setiap kelompok mengajukan pertanyaan yang mereka buat tadi untuk djawab oleh kelompok lain. Kelompok yang menjawab dengan tepat akan mendapat poin 10. Ini yang disebut sebagai competition. Sedangkan ketiga adalah kegiatan penutup. Kegiatan ini berlangsung selama 20 menit dengan membahas materi yang sudah diterima. Dosen membantu mahasiswa menyimpulkan materi hari itu.

Pertemuan kedua. Pertemuan kedua dilaksanakan pada hari Jumat tanggal 12 Mei 2017 dengan rincian kegiatan sebagai berikut: pertama kegiatan pembukaan, Seperti biasa dosen memberi salam, brainstorming dan mengulang materi pada pertemuan sebelumnya. Kegiatan ini berlangsung pada 20 menit pertama. Kedua kegiatan inti. Kegiatan ini dilaksanakan selama 60 menit dengan tahapan yang sama dengan pertemuan pertama. Sebelumnya, dosen bertanya mengenai kesulitan yang dihadapi oleh mahasiswa selama proses pembelajaran pada pertemuan pertama. Dan yang terakhir adalah kegiatan penutup. Dalam 20 menit terakhir ini kegiatan dilakukan dengan tanya jawab sebagai evaluasi.

Pertemuan ketiga, Pertemuan ketiga ini dilaksanakan pada hari Selasa tanggal 16 Mei 2017 dengan rincian kegiatan sebagai berikut: pertama kegiatan pembukaan. Dalam kegiatan ini dosen mengucapkan salam pembuka, brainstorming, dan bertanya mengenai materi pertemuan sebelumnya. Selanjutnya adalah kegiatan inti, kegiatan inti diisi dengan dosen memberi teks kepada mahasiswa seperti halnya pada proses inti pertemuan 1 dan 2 . Proses ini berlangsung selama 60 menit. Dan yang terakhir adalah kegiatan penutup. Kegiatan ini dilakukan selama 20 menit dengan bersama-sama menyimpulkan materi hari itu. Dosen memberitahu bahwa pertemuan selanjutnya adalah tes.

Pertemuan keempat. Pertemuan keempat dilaksanakan pada hari Jumat tanggal 19 Mei 2017 dengan rincian 
kegiatan sebagai berikut: kegiatan Pembukaan, Dosen memberi salam pembuka, brainstorming dan mempersiapkan mahasiswa untuk mengerjakan tes yang bertujuan untuk mengetahui apakah penggunaan $\mathrm{C} \& \mathrm{C}$ Learning dapat meningkatkan ketrampilan membaca mahasiswa. Kedua adalah kegiatan Inti. Dosen memberikan secara singkat mengenai tes yang akan dilaksanakan oleh mahasiswa. Dalam tes ini mahasiswa mendapatkan beberapa teks bacaan dan menjawab pertanyaan sesuai dengan bacaan. Dan yang terakhir adalah $\mathrm{k}$ egiatan Penutup. Mahasiswa mengumpulkan hasil tes dan dosen mengucapkan salam penutup.

\section{Pengamatan}

Pada siklus pertama ini bisa ditarik kesimpulan bahwa mahasiswa mempunyai antusiasme yang tinggi dalam mengikuti penerapan $\mathrm{C} \& \mathrm{C}$ Learning, namun ada beberapa mahasiswa yang lambat memahami apa yang harus dilakukan sehingga mereka tampak tidak bisa mengikuti dan mengerjakan tugas yang diberikan oleh dosen dengan baik. Hal ini terjadi pada pertemuan pertama.

Pada pertemuan kedua, sebelum proses pembelajaran berlangsung, dosen berinteraksi dengan mahasiswa dengan bertanya jawab mengenai kesulitan yang ditemui mahasiswa pada pertemuan sebelumnya. Dosen memberi penjelasan kembali mengenai jalannya proses pembelajaran dengan menggunakan $\mathrm{C} \&$ $\mathrm{C}$ Learning. Disini dapat diambil kesimpulan bahwa mahasiswa dan dosen mempunyai interaksi yang lebih baik dari sebelumnya.

Pada pertemuan ketiga mahasiswa sudah memahami apa yang harus dilakukan dan mereka berlomba menjawab pertanyaan yang diajukan oleh kelompok lain. Namun konsekuensinya adalah situasi kelas ramai.

Pada pertemuan ke empat mahasiswa mengerjakan tes yang diberikan oleh dosen. Hampir semua mahasiswa mengerjakan soal dengan tenang yang menandakan mereka mampu mengerjakan soal yang diberikan, namun tampak masih ada mahasiswa yang tampak kesulitan dalam pengerjaan soal yang ditandai dengan berkali-kali memukulkan pensil ke kursi dan mengernyitkan dahi.

\section{Evaluasi Penerapan C\&C Learning}

Berdasarkan pengamatan yang dilakukan selama proses pembelajaran pada siklus pertama, peneliti menemukan beberapa permasalahan. Yang pertama adalah ada mahasiswa yang tidak bisa bekerja sama dalam kelompok. Mahasiswa tersebut selalu ingin mendominasi. Semua ingin dilakukan sendiri tanpa mengindahkan teman yang lain. Di lain kelompok didapati justru sebaliknya ada mahasiswa yang tampaknya hanya ingin mengandalkan kepandaian teman, jadi mahasiswa tersebut pasif. Padahal hendaknya diketahui meskipun bekerja bersama tim namun hendaknya peran individu tetap ada, karena pada akhirnya penilaian bersifat individu. Permasalahan yang lain adalah suasana kelas tidak terkontrol atau ramai.

Criteria keberhasilan yang ditetapkan oleh peneliti adalah $80 \%$ dari seluruh kelas mendapat nilai akhir 80 . Pada tabel 3.2 dapat dilihat bahwa mahasiswa yang mencapai nilai akhir 80 adalah $46,15 \%$ sedangkan $53,85 \%$ masih memperoleh nilai di bawah 80 . Berdasarkan hal tersebut maka peneliti memutuskan melanjutkan ke siklus kedua. Secara detail dapat dilihat pada tabel 3.2 
ISSN : 23557083

Volume 4 Nomor 1 Juni 2017

Table 3.2 Hasil Tes Siklus 1

\begin{tabular}{llll} 
No & Jumlah mahasiswa & Jumlah & Prosentase(\%) \\
\hline 1 & Dibawah 80 & 12 & 46.15 \\
2 & Diatas 80 & 14 & 53.85 \\
\hline & Total & 26 & 100
\end{tabular}

Capaian pada siklus pertama adalah sebanyak 12 mahasiswa mendapat nilai dibawa nilai yang ditentukan dalam kriteria ketuntasan atau dapat disebutkan pada tahap perencanaan kriteria kesuksesan adalah Criteria keberhasilan yang ditetapkan oleh peneliti adalah $80 \%$ dari seluruh kelas mendapat nilai akhir 80. maka penelitian pada sikuls pertama dinyatakan kurang berhasil dan peneliti melanjutkan ke siklus kedua.

\section{Siklus 2}

Siklus kedua dilaksanakan pada tanggal 31 Mei, 2 juni, 6 Juni, dan 9 Juni 2017. Proses penerapan C\&C Learning masih sama dengan siklus 1, dan tahapan nya pun masih sama yakni perencanaan, penerapan, pengamatan, dan evaluasi.

Berdasarkan penemuan permasalahan yang timbul pada siklus 1 , maka peneliti memutuskan untuk memperbaiki sistem dalam penerapan pembelajaran dengan menggunakan C\&C Learning. Hal yang berubah adalah peneliti memutuskan untuk memperkecil jumlah mahasiswa dalam satu kelompok dan memperbaiki materi yang diberikan kepada mahasiswa.

Tahap penerapan/pelaksanaan. kedua metode di siklus dua adalah 4 pertemuan yang terdiri dari 3 pemberian materi dan 1 pertemuan untuk tes. Hal ini dijelaskan lebih rinci sebagai berikut:

Pertemuan pertama. Pertemuan pertama siklus kedua dilaksanakan pada hari Rabu tanggal 31 Mei 2017 dengan rincian kegiatan sebagai berikut: pertama kegiatan pembuka. Dalam 20 menit pertama ini, dosen mengucapkan salam pembuka, brainstorming, dan menjelaskan perubahan dan tujuan yang diharapkan. Kedua kegiatan inti. Kegiatan ini berlangsung selama 60 menit dengan diawali pembentukan kelompok. Dosen menjelaskan kembali proses pembelajaran C\&C Learning. Ketiga adalah kegiatan penutup. Kegiatan ini berlangsung selama 20 menit dengan membahas dan menyimpulkan materi pada hari tersebut.

Pertemuan kedua dilakukan pada hari Jumat tanggal 2 Juni 2017 dngan rincian kegiatan sebagai berikut: pertama, kegiatan pembuka. Dosen membuka dengan mengucapkan salam pembuka, brainstorming, dan membahas materi pertemuan sebelumnya. Kedua. Kegiatan inti, sebelum dosen memberi teks bacaan kepada mahasiswa, dosen bertanya jawab dulu mengenai kesulitan yang dihadapi oleh mahasiswa dan mengingatkan mahasiswa meskipun bekerja sama dalam kelompok namun pada akhirnya penuliannya adalah secara individu. Ketiga kegiatan Penutup. Kegiatan ini berlangsung selama 20 menit dengan menyimpulkan materi yang baru saja diberikan.

Pertemuan ketiga dilakukan pada hari Selasa tanggal 6 Juni 2017 dngan rincian kegiatan sebagai berikut: pertama, kegiatan pembuka. Dosen membuka dengan mengucapkan salam pembuka, brainstorming, dan membahas materi pertemuan sebelumnya. Kedua kegiatan inti. Dosen memberi kesempatan pada mahasiswa untuk bertanya sebelum dosen memberikan teks bacaan kepada mahasiswa. Terakhir kegiatan penutup. Kegiatan penutup selama 20 menit ini dilakukan dengan menyimpulkan materi pada hari tersebut dan mengingatkan mahasiswa bahwa pada pertemuan berikutnya adalah tes. 
Pertemuan keempat dilaksanakan pada hari Jumat tanggal 9 Juni 2017 dengan rincian kegiatan sebagai berikut: pertama, kegiatan pembukaan. Dosen memberi salam pembuka, brainstorming dan mempersiapkan mahasiswa untuk mengerjakan tes yang bertujuan untuk mengetahui apakah penggunaan $\mathrm{C} \& \mathrm{C}$ Learning dapat meningkatkan ketrampilan membaca mahasiswa. Kegiatan inti, Dosen memberikan secara singkat mengenai tes yang akan dilaksanakan oleh mahasiswa. Dalam tes ini mahasiswa mendapatkan beberapa teks bacaan dan menjawab pertanyaan sesuai dengan bacaan. Tarkhir, kegiatan penutup. Mahasiswa mengumpulkan hasil tes dan dosen mengucapkan salam penutup.

\section{Pengamatan siklus 2}

Pada siklus kedua ini bisa ditarik kesimpulan bahwa pada pertemuan pertama, dengan meminta mahasiswa untuk memilih sendiri anggota kelompoknya, tujuan peneliti bahwa mereka bisa bekerja sama dengan lebih baik tercapai.

Pada pertemuan kedua, mahasiswa tampak lebih antusias dalam memberikan pendapatnya untuk membuat pertanyaan maupun dalam menjawab pertanyaan dari kelompok lain. Pada pertemuan ketiga, mahasiswa sudah tampak lebih santai dan bisa mengendalikan diri sehingga kelas sudah tidak terlalu ramai.

Pada pertemuan ke empat yakni pengerjaan tes, mahasiswa sudah tampak lebih percaya diri dan tidak ada yang mahasiswa yang tampak bingung ataupun melamun seperti pada saat mereka melakukan tes pada siklus pertama. Mahasiswa tampak lebih santai namun serius dan lebih berhati-hati dalam mengerjakan soal.

\section{Evaluasi siklus 2}

Dari hasil pengamatan dapat diambil kesimpulan bahwa penerapan C\&C Learning memberikan perasaan yang lebih santai dan perasaan tidak tertekan bagi mahasiswa. Kondisi seperti ini penting sehingga mahasiswa tidak merasa bosan dan dengan bebas menuangkan ide mereka untuk menjawab dan membuat pertanyaan sehingga pembelajaran mata kuliah membaca terasa lebih menyenangkan dan diharapkan dengan kondisi yang kondusif seperti hal tersebut di atas maka bisa menaikkan ketrampilan membaca mereka.

Tabel 3.3 Hasil Tes Siklus 2

\begin{tabular}{llll}
\hline No & Jumlah mahasiswa & Jumlah & Prosentase(\%) \\
\hline 1 & Dibawah 80 & 3 & 11.54 \\
2 & Diatas 80 & 23 & 88.46 \\
\hline \multicolumn{2}{l}{ total } & 26 & 100
\end{tabular}

Berdasarkan pada tabel diatas jumlah mahasiswa yang mencapai criteria keberhasilan sudah memenuhi syarat $88.46 \%$ atau sebanyak 23 mahasiswa memperoleh nilai 80 dan diatasnya, sedangkan jumlah mahasiswa ynag memperoleh nilai di bawah 80 adalah sebanyak 3 mahasiswa (11.54\%) maka hasil siklus kedua ini sudah memenuhi kriteria keberhasilan yang telah ditetapkan peneliti pada tahap perencanaan yaitu $80 \%$ dari seluruh kelas mendapat nilai akhir 80. Peneliti menyimpulkan bahwa penelitian pada siklus kedua dinyatakan berhasil karena sudah emmenuhi kriteria keberhasilan yang telah ditentukan.

\section{Pembahasan}

\section{Hasil kuesioner}

Tanggapan mahasiswa dalam bentuk respon terhadap kuesioner yang dibagikan terbagi atas 3 variabe yang diukur yakni: 1) kemampuan 
ISSN : 23557083

Volume 4 Nomor 1 Juni 2017

berinteraksi, menuangkan ide, 3) hasil belajar.

a. Kemampuan berinteraksi

Variable pertama mendapat tanggapan yang sangat baik dari mahasiswa. Pernyataan "saya bisa bekerja bersama dalam kelompok dengan situasi yang menyenangkan" dan "C\&C Learning membuat saya bisa mempunyai banyak waktu untuk berinteraksi dengan teman" dipilih oleh $24(92,30 \%)$ mahasiswa.

b. Kemampuan menuangkan ide Variable kedua juga mendapatkan tanggapan yang sangat bagus. Penyataan "saya bisa mengemukakan ide dengan cara membuat pertanyaan tanpa merasa terbebani" mendapat tanggapan 25 $(96,15 \%)$ dari mahasiswa. Sedangkan pernyataan "saya bisa menjawab pertanyaan dengan lebih mudah mendapat tanggapan persetujuan dari 23 $(88,46 \%)$ mahasiswa.

\section{Hasil Belajar}

Variable ketiga mendapatkan tanggapan yang sangat memuaskan dari mahasiswa, yakni $26(100 \%)$ mahasiswa setuju pada pernyataan bahwa pembelajaran dengan menggunakan $\mathrm{C} \& \mathrm{C}$ Learning membuat mahasiswa (1) lebih mudah mempelajari teks bacaan yang baru, (2) mengingat materi baru dangan lebih mudah, (3) menimbulkan rasa percaya diri.

2. Permasalahan yang dihadapi selama penerapan C\&C Learning dapat digambarkan sebagai berikut:

a. Dominasi beberapa mahasiswa. Pada saat kegiatan pembelajaran berlangsung, ada beberapa mahasiswa yang mendominasi peran di grup, baik pada saat membuat pertanyaan ataupun pada saat menjawab pertanyaan. Hal ini membuat mahasiswa yang kurang bisa merasa minder.

b. Ramai. Situasi kelas terkadang ramai terutama pada saat sesi menjawab pertanyaan dari grup lain. Karen aitu diperlukan dosen atau guru yang berwibawa dan juga perjajian di awal supaya mahasiswa bisa lebih mengontrol diri.

c. Salah persepsi dalam mengartikan kata "cooperative" atau bekerja sama. Ada beberapa mahasiswa yang mengartikan bekerja sama adalah selalu dibantu oleh orang lain. Mahasiswa tersebut tidak mau berfikir secara indivisu terlebih dahulu namun cenderung mengandalkan teman.

\section{Hasil Capaian}

Penelitian ini menggunakan metode penelitian tindakan kelas dengan mengaplikasikan 2 siklus. Pada siklus yang pertama, pencapaian yang dihasilkan adalah sebagai berikut:

Capaian pada siklus pertama adalah: jumlah mahasiswa ynag memeproleh nilai kurang dari 80 sebanyak12 mahasiswa (46.15\%) sedangkan yang memperoleh nilai 08 dan diatasnya sebanyak 14 mahasiswa. Karena jumlah mahasiswa yang mencapai criteria keberhasilan masih di bawah target peneliti, maka peneliti memutuskan untuk melanjutkan ke siklus ke 2 denagn beberapa rivisi pada tahap perencanaan berdasarkan hasil pengamatan pada siklus pertama.

Capaian pada siklus kedua adalah: jumlah mahasiswa yang mencapai criteria keberhasilan sudah memenuhi syarat $88.46 \%$ atau sebanyak 23 mahasiswa memperoleh nilai 80 dan diatasnya, sedangkan jumlah mahasiswa ynag memperoleh nilai di bawah 80 adalah sebanyak 3 mahasiswa (11.54\%) maka hasil siklus kedua ini sudah 
ISSN : 23557083

Volume 4 Nomor 1 Juni 2017

memenuhi kriteria keberhasilan yang telah ditetapkan peneliti pada tahap perencanaan yaitu $80 \%$ dari seluruh kelas mendapat nilai akhir 80. Peneliti menyimpulkan bahwa penelitian pada siklus kedua dinyatakan berhasil karena sudah emmenuhi kriteria keberhasilan yang telah ditentukan.

\section{KESIMPULAN}

Dari hasil dan pembahasan diatas dapat disimpulkan bahwa penggunaan C\&C Learning sangatlah mampu dalam meningkatkan kemampuan berfikir kreatif dan berdaya saing positif dalam pembelajaran Reading. Pembelajaran Reading di kelas berjalan sangat kondusif dan menyenangkan. Disatu sisi dengan cooperative learning, mahasiswa mampu bekerja sama satu dengan yang lainnya sedangkan disisi yang lain, dengan kompetitive learning mahasiswa tetap terakomodir dalam meningkatkan kemampuannya secara individual. Maka dari itu C\&C Learning dapat diterapkan dikelas Reading. Bagi peneliti yang tertarik meneliti dalam bidang strategi penelitian, hasil penleitian ini dapat dijasikan sebagai referensi. Bagi peneliti yang akan datang dihharapkan dapat menerapkan C\&C Learning dalam bidang yang lain misalnya pada matakuliah speaking ataupun writing.

\section{DAFTAR PUSTAKA}

Brown, H. D. 2007. Teaching by Principles: An Interactive Approach to Language Pedagogy. Englewoods Cliffs: Prentice Hall.

Cooper, J. M. 1999. Classroom Teaching Skill. Boston: Houghton Mifflin Company.

Gebhard, J. G. 2000. Teaching English as a Foreign Language or Second Language: A Teacher Self Development and Methodology Guide. Michigan: the University of Michigan Press.

Kemmis, S.,\& Mc Taggart, R. 1988. The Action Research Planner. Victoria: Deakin University Press.

Kholid A. H dan Lilis S. (1997). Pembelajaran Bahasa Indonesia di Sekolah Dasar. Jakarta : Universitas Terbuka.

Richard, J., \& Rodgers, T. 2002. Approaches and Methods in Language Teaching. Cambridge: Cambridge University Press.

Soedarso. 2006. Sistem Membaca Cepat dan Efektif. Jakarta: Gramedia Pustaka Utama. 